\title{
Costertonia aggregata gen. nov., sp. nov., a mesophilic marine bacterium of the family Flavobacteriaceae, isolated from a mature biofilm
}

Correspondence Hong Kum Lee hklee@kopri.re.kr

\author{
Kae Kyoung Kwon, ${ }^{1}$ Yoo Kyung Lee ${ }^{2}$ and Hong Kum Lee ${ }^{2}$
}

Marine Biotechnology Research Center ${ }^{1}$ and Polar BioCenter, Korea Polar Research Institute ${ }^{2}$, Korea Ocean Research and Development Institute, Ansan PO Box 29, 425-600, Republic of Korea

\begin{abstract}
A marine bacterium, strain KOPRI $13342^{\top}$, was isolated from a mature marine biofilm, including various marine algae, covering a rock-bed of the East Sea, Korea (also known as the Sea of Japan). Colonies of the isolate were orange-coloured on marine agar 2216. The isolate showed relatively high $16 \mathrm{~S}$ rRNA gene sequence similarities to members of the genera Maribacter

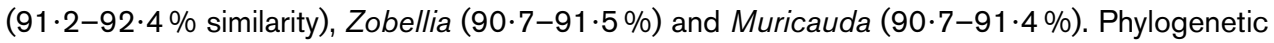
analysis based on the nearly complete $16 \mathrm{~S}$ rRNA gene sequence revealed that the isolate formed a phyletic lineage with members of the genus Muricauda. Cells were aerobic, motile, Gram-negative rods and they produced non-diffusible carotenoid pigments. Optimal growth was observed at $\mathrm{pH} 7 \cdot 5-8 \cdot 0$ and $26-32{ }^{\circ} \mathrm{C}$ and required the presence of $3 \%(\mathrm{w} / \mathrm{v})$ sea salt. The strain required $\mathrm{Ca}^{2+}$ and $\mathrm{K}^{+}$ions in addition to $\mathrm{NaCl}$ for growth. The dominant fatty acids were $\mathrm{i}-15: 0$, $\mathrm{i}-15: 1 \omega 10,15: 0$ and $16: 1 \omega 9$. The major respiratory quinone was MK-6. The DNA G + C content was $35.8 \mathrm{~mol} \%$. On the basis of this polyphasic taxonomic evidence, strain KOPRI $13342^{\top}$ should be classified as a representative of a novel species in a new genus in the family Flavobacteriaceae; the name Costertonia aggregata gen. nov., sp. nov. is proposed. The type strain of Costertonia aggregata is KOPRI $13342^{\top}\left(=\operatorname{KCCM~} 42265^{\top}=\mathrm{JCM} 13411^{\top}\right)$.
\end{abstract}

Bacteria in nature often exist as sessile multispecies communities called biofilms (Costerton et al., 1995). In oligotrophic marine environments, bacterial colonization on surfaces is regarded as a microbial survival strategy that provides micro-organisms with important advantages, including increased access to nutrients, protection against toxins and antibiotics and retention of signal molecules (Jefferson, 2004; Pasmore \& Costerton, 2003). Direct observations of a wide variety of natural ecosystems have established that the vast majority of bacteria in most aquatic environments grow within matrix-enclosed biofilms (Costerton et al., 1994). Therefore, biofilms could serve as a source of diverse micro-organisms and many novel bacterial strains have been reported from marine biofilm matrices including algal surfaces (Gillan et al., 1998; Golyshin et al., 2002; Matsuo et al., 2003; Patel et al., 2003; Nedashkovskaya et al., 2004a, b, 2005; Bowman \& Nichols, 2005; Lau et al., 2004). Of these, up to $30 \%$ could be affiliated with the phylum Bacteroidetes (Webster et al., 2004). We have also isolated many bacteria belonging to the family Flavobacteriaceae from mature biofilms; taxonomic analysis of a novel strain, KOPRI $13342^{\mathrm{T}}$, is described herein.

The GenBank/EMBL/DDBJ accession number for the 16S rRNA gene sequence of strain KOPRI $13342^{\top}$ is DQ167246.
Approximately $10 \mathrm{~cm}^{3}$ biofilm consisting of diverse algal species on a rock-bed was harvested using a razor blade and dispersed in $30 \mathrm{ml}$ sterilized seawater. The dispersed biofilm was spread on marine agar 2216 (MA; Difco) after serial dilution with sterilized seawater and cultivated at $25^{\circ} \mathrm{C}$ for a week. Among the distinct colonies that grew on MA, a tiny, orange-coloured colony was isolated, strain KOPRI $13342^{\mathrm{T}}$, and preserved in $20 \%$ glycerol solution at $-80^{\circ} \mathrm{C}$. The isolate was further cultivated on MA for morphological and biochemical characterization.

Unless otherwise stated, methods used for physiological and morphological characterization were as described previously (Sohn et al., 2004b; Kwon et al., 2005). The degradation of starch and casein by strain KOPRI $13342^{\mathrm{T}}$ was tested according to Smibert \& Krieg (1994). Physiological, biochemical and morphological characteristics of strain KOPRI $13342^{\mathrm{T}}$ are given in the genus and species descriptions and in Table 1.

$\mathrm{NaCl}, \mathrm{Mg}^{2+}$ and/or $\mathrm{Ca}^{2+}$ requirements were tested according to Sohn et al. (2004a). However, no growth was observed in the presence of $\mathrm{NaCl}$ alone or in the presence of $\mathrm{Mg}^{2+}$ and $\mathrm{Ca}^{2+}$ ions, so other components found in seawater were tested. Tested elements and their concentrations were described by Parsons et al. (1984). Combinations of four 
Table 1. Phenotypic characteristics that differentiate strain KOPRI $13342^{\top}$ from closely related members of the family Flavobacteriaceae

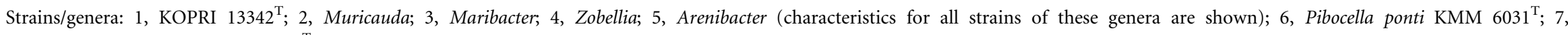

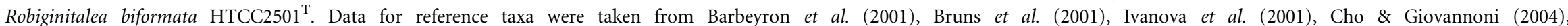

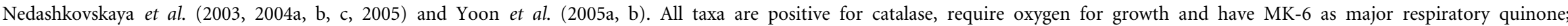
none of the strains requires specific growth factors or produces indole. ND, Not determined; $v$, variable.

\begin{tabular}{|c|c|c|c|c|c|c|c|}
\hline Characteristic & 1 & 2 & 3 & 4 & 5 & 6 & 7 \\
\hline Cell size $(\mu \mathrm{m})$ & $0 \cdot 35-0 \cdot 41 \times 0 \cdot 50-4 \cdot 25$ & $0 \cdot 2-0 \cdot 6 \times 1 \cdot 1-6 \cdot 0$ & $0 \cdot 4-0 \cdot 5 \times 2 \cdot 0-10 \cdot 0$ & $0 \cdot 3-0 \cdot 5 \times 1 \cdot 2-8 \cdot 0$ & $0 \cdot 4-0 \cdot 7 \times 3 \cdot 0-5 \cdot 0$ & $0 \cdot 4-0 \cdot 5 \times 0 \cdot 6-2 \cdot 3$ & $0.3-0.7 \times 1.6-5.6$ \\
\hline Gliding motility & - & $+/ \mathrm{ND}$ & + & + & - & + & - \\
\hline \multicolumn{8}{|l|}{ Tolerance of: ${ }^{*}$} \\
\hline Temperature $\left({ }^{\circ} \mathrm{C}\right)$ & $10-35(26-32)$ & $8-44(20-30,30-37) \dagger$ & $4-33(21-24)$ & $4-45(21-35)$ & $4-42(28-30)$ & $4-33(21-24)$ & $10-44(30)$ \\
\hline $\mathrm{pH}$ & $6 \cdot 5-9 \cdot 0(7 \cdot 5-8 \cdot 0)$ & $6 \cdot 0-8 \cdot 0(6 \cdot 5-7 \cdot 5)$ & $5 \cdot 5-10 \cdot 0(7 \cdot 5-8 \cdot 5)$ & ND & $5 \cdot 5-10(7 \cdot 5-8 \cdot 5)$ & ND & $6-9(8-8 \cdot 5)$ \\
\hline Salt concentration (\%) & $1 \cdot 5-12 \cdot 0(3 \cdot 0)$ & $0 \cdot 5-9 \cdot 0(2 \cdot 0-3 \cdot 0)$ & $1 \cdot 0-7 \cdot 0(1 \cdot 5-2 \cdot 0)$ & $0 \cdot 5-10 \cdot 0(2 \cdot 0-3 \cdot 0)$ & $1-10$ & $1-13$ & $0 \cdot 25-10(2 \cdot 5)$ \\
\hline Seawater requirement $\neq$ & + & - & - & - & - & - & - \\
\hline Oxidase activity & + & $\mathrm{v}$ & + & + & + & + & + \\
\hline Nitrate reduction & + & - & $\mathrm{v}$ & + & + & - & - \\
\hline \multicolumn{8}{|l|}{ Production of: } \\
\hline Urease & - & - & - & - & $\mathrm{V}$ & - & - \\
\hline $\mathrm{H}_{2} \mathrm{~S}$ & - & - & - & - & $\mathrm{v}$ & - & - \\
\hline Acid from carbohydrate & - & $\mathrm{v}$ & $\mathrm{v}$ & $\mathrm{V}$ & $\mathrm{v}$ & + & - \\
\hline \multicolumn{8}{|l|}{ Hydrolysis of: } \\
\hline Agar & - & - & $\mathrm{v}$ & + & - & - & $\mathrm{ND}$ \\
\hline Casein & - & - & - & - & - & + & - \\
\hline Gelatin & + & - & $\mathrm{v}$ & + & $\mathrm{v}$ & + & - \\
\hline Starch & - & - & $\mathrm{v}$ & $\mathrm{V}$ & - & + & + \\
\hline \multicolumn{8}{|l|}{ Major fatty acids $§$} \\
\hline $\mathrm{i}-15: 0$ & $39 \cdot 7$ & $14 \cdot 7-23 \cdot 8$ & $10 \cdot 6-20 \cdot 5$ & $16 \cdot 8-22 \cdot 5$ & $8 \cdot 5-17 \cdot 3$ & $8 \cdot 7$ & $24-28$ \\
\hline $\mathrm{i}-15: 1 \omega 10$ & $22 \cdot 4$ & $19 \cdot 5-21 \cdot 6$ & $10 \cdot 1-18 \cdot 9$ & $8 \cdot 8-14 \cdot 9$ & $14 \cdot 3-19 \cdot 3$ & $11 \cdot 7$ & $14-21$ \\
\hline$a-15: 0$ & & & & & $6 \cdot 6-8 \cdot 6$ & $5 \cdot 4$ & $3-4$ \\
\hline $15: 0$ & $7 \cdot 8$ & $5 \cdot 1-13 \cdot 2$ & $3 \cdot 5-14 \cdot 5$ & $7 \cdot 5-14 \cdot 4$ & $13 \cdot 3-29 \cdot 0$ & $4 \cdot 2$ & $5-6$ \\
\hline $\mathrm{i}-16: 0$ & & & & & & $12 \cdot 1$ & \\
\hline$i-16: 1$ & & & & & & $6 \cdot 2$ & \\
\hline $16: 1 \omega 9$ & $4 \cdot 6$ & & & & $<5-11 \cdot 0$ & & \\
\hline $\mathrm{i}-17: 1$ & & & $2 \cdot 0-4 \cdot 0$ & $2 \cdot 4-5 \cdot 1$ & & $5 \cdot 2$ & \\
\hline $\mathrm{i}-15: 03-\mathrm{OH}$ & & $4 \cdot 6-5 \cdot 5$ & $2 \cdot 9-5 \cdot 4$ & $4 \cdot 6-8 \cdot 3$ & & & $4 \cdot 3$ \\
\hline $\mathrm{i}-16: 03-\mathrm{OH}$ & & $1 \cdot 7-4 \cdot 6$ & & & & $5 \cdot 9$ & \\
\hline $\mathrm{i}-17: 03-\mathrm{OH}$ & & $17 \cdot 3-20 \cdot 9$ & $11 \cdot 6-29 \cdot 2$ & $15 \cdot 1-25 \cdot 9$ & $<5-6 \cdot 1$ & $5 \cdot 6$ & $25-27$ \\
\hline Summed feature $3 \|$ & & $2 \cdot 3-4 \cdot 2$ & $5 \cdot 8-12 \cdot 9$ & $9 \cdot 9-15 \cdot 5$ & & $11 \cdot 4$ & \\
\hline Unknown & & $7 \cdot 0-8 \cdot 8$ & $2 \cdot 7-10 \cdot 3$ & & & $5 \cdot 5$ & \\
\hline DNA G $+\mathrm{C}$ content $(\mathrm{mol} \%)$ & $35 \cdot 8$ & $41-45 \cdot 4$ & $35-39$ & $36-43$ & $37 \cdot 5-40$ & $35 \cdot 5$ & $55-56$ \\
\hline
\end{tabular}

${ }^{\star}$ Ranges with optima shown in parentheses.

$\nmid$ The genus Muricauda contains two different groups with different optimal growth temperature ranges.

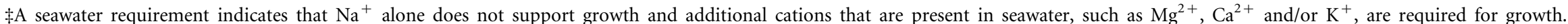
$\$$ Fatty acids present at less than $3 \%$ of the total fatty acids in all strains were not included.

일 IIContains $16: 1 \omega 7 c$ and/or i-15:0 $2-\mathrm{OH}$. 
major components $\left(\mathrm{CaCl}_{2} \cdot 2 \mathrm{H}_{2} \mathrm{O}, \mathrm{KCl}, \mathrm{MgCl}_{2} \cdot 6 \mathrm{H}_{2} \mathrm{O}\right.$ and $\left.\mathrm{Na}_{2} \mathrm{SO}_{4}\right)$ and a mixture of five trace components $\left(\mathrm{H}_{3} \mathrm{BO}_{3}\right.$, $\mathrm{KBr}, \mathrm{Na}_{2} \mathrm{CO}_{3}, \mathrm{NaF}$ and $\mathrm{SrCl}_{2} \cdot 6 \mathrm{H}_{2} \mathrm{O}$ ) were supplied to the DW substituted (including $3 \% \mathrm{NaCl}$ ) ZoBell 2216e medium. Growth was observed in the presence of $\mathrm{Ca}^{2+}$ and $\mathrm{K}^{+}$ions in addition to $\mathrm{NaCl}$.

The profile of cellular fatty acid methyl esters was determined according to Sohn et al. (2004b). The dominant fatty acids of KOPRI $13342^{\mathrm{T}}$ were i-15:0 (39.7\%), i-15: $1 \omega 10$ $(22 \cdot 4 \%), 15: 0(7 \cdot 8 \%)$ and $16: 1 \omega 9(4 \cdot 6 \%)$. The strain also contained small amounts of 16:0 $(2 \cdot 7 \%), \mathrm{C}_{18}$ polyunsaturated fatty acids $(2 \cdot 5 \%), 18: 0(2 \cdot 2 \%), 13: 0(2 \cdot 0 \%), 10-$

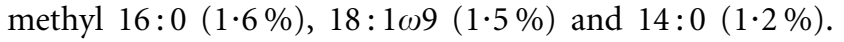
The isolate contained a relatively large amount of $i-15: 0$ compared with that found in members of closely related genera in the family Flavobacteriaceae (Table 1).

The major respiratory quinone was determined to be menaquinone by the reverse-phase-TLC method described by Kim et al. (2000) and confirmed to be MK-6 by HPLC analysis according to the method described by Collins (1985). The DNA G $+C$ content was $35 \cdot 8 \mathrm{~mol} \%$, as determined by the thermal denaturation method (Kim et al., 2000).

Genomic DNA extraction and amplification and sequencing of the 16S rRNA gene were carried out according to Sohn et al. (2004b). A phylogenetic tree including strain KOPRI $13342^{\mathrm{T}}$ and members of closely related genera was generated based on the maximum-likelihood distance model and the neighbour-joining method. 16S rRNA gene sequences of Bacteroides fragilis ATCC $25285^{\mathrm{T}}$ (GenBank accession no. NC_003228) and Sphingobacterium spiritivorum DSM $2582^{\mathrm{T}}$ (AJ459411) served as outgroups. A total of 1331 unambiguously aligned positions was compared. The closest neighbour was Maribacter dokdonensis DSW $-8^{\mathrm{T}}(92 \cdot 4 \%$ sequence similarity), followed by Maribacter sedimenticola KMM $3903^{\mathrm{T}}(92 \cdot 1 \%)$ and Maribacter orientalis KMM $3947^{\mathrm{T}}$ (92.0\%). Members of the genera Zobellia and Muricauda showed a similar range of similarities (90.7-91.5 and 90.7$91 \cdot 4 \%$, respectively) to strain KOPRI $13342^{\mathrm{T}}$. Phylogenetic analysis of $16 \mathrm{~S}$ rRNA gene sequences from organisms with validly published names revealed that strain KOPRI $13342^{\mathrm{T}}$ shared a phyletic line with members of the genus Muricauda. This small clade lies within a larger clade containing the genera Arenibacter, Maribacter, Pibocella and Zobellia (Fig. 1).

Strain KOPRI $13342^{\mathrm{T}}$ shared many characteristics, including major respiratory quinone type, oxygen requirement and temperature range, $\mathrm{pH}$ and salt concentration for growth, with closely related members of the family Flavobacteriaceae. However, the strain required an additional seawater component in addition to $\mathrm{NaCl}$ (Table 1) and contained a larger amount of i-15:0 fatty acid, enabling it to be differentiated from other members of the family Flavobacteriaceae. Hence, it is proposed that strain KOPRI $13342^{\mathrm{T}}$ should be identified as a representative of a novel species in a new genus in the family Flavobacteriaceae, Costertonia aggregata gen. nov., sp. nov.

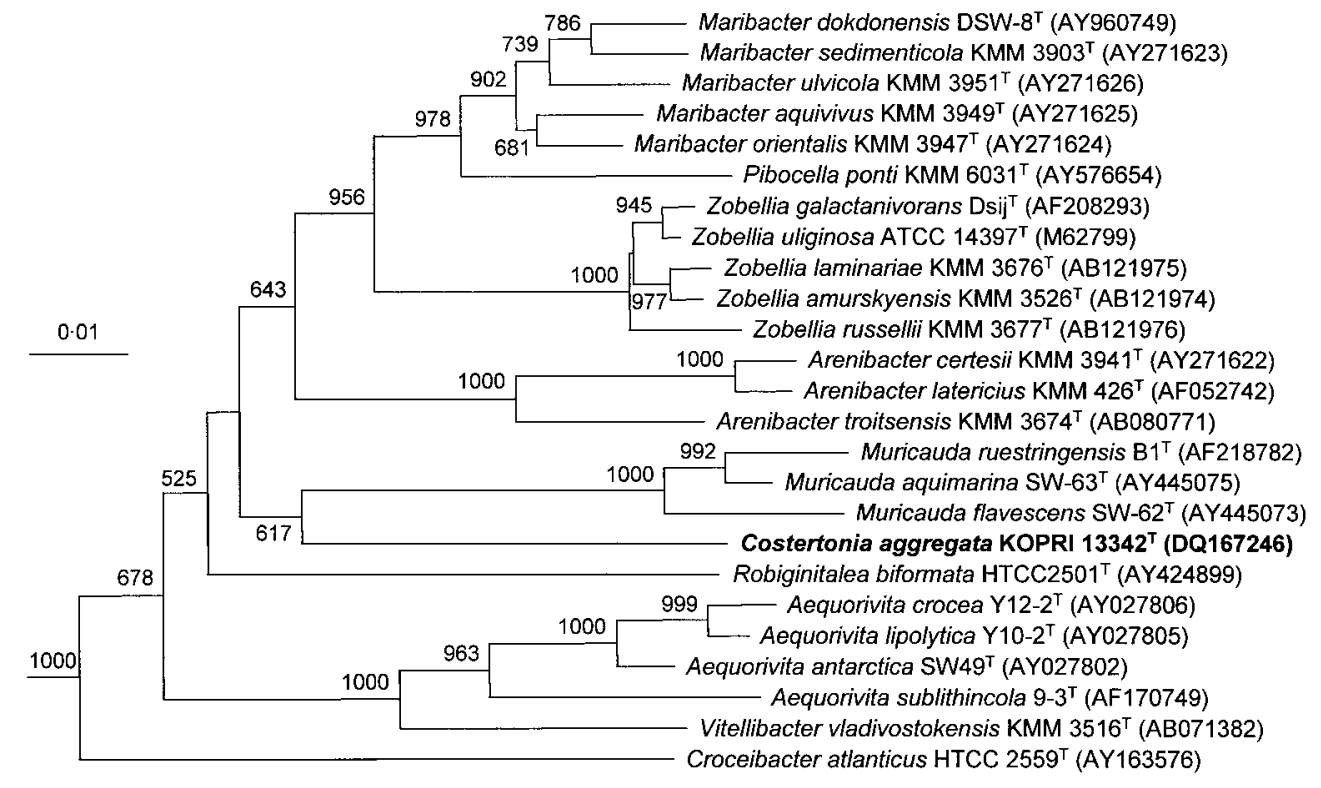

Fig. 1. Phylogenetic tree based on nearly complete $16 \mathrm{~S}$ rRNA gene sequences (1321 unambiguously aligned base pairs) showing the relationship between strain KOPRI $13342^{\top}$ and other members of the family Flavobacteriaceae. The tree is based on the maximum-likelihood distances model and the neighbour-joining method. Bootstrap values $>50 \%$ of 1000 resampled are shown. Bar, $0 \cdot 01$ substitutions per nucleotide position. 


\section{Description of Costertonia gen. nov.}

Costertonia (Cos.ter.ton'i.a. N.L. fem. n. Costertonia honouring J. W. Costerton, a famous American biofilm microbiologist).

Cells are aerobic, motile, Gram-negative rods. Gliding motility is absent. Orange-coloured colonies form on MA. Produce non-diffusible carotenoid pigments, but flexirubin-type pigments are absent. The major respiratory quinone is MK6. The major cellular fatty acids are $\mathrm{i}-\mathrm{C} 15: 0, \mathrm{i}-\mathrm{C} 15: 1$ and $15: 0$. Oxidase- and catalase-positive. As determined by $16 \mathrm{~S}$ rRNA gene sequence analysis, the genus Costertonia is a member of the family Flavobacteriaceae, phylum Bacteroidetes. The type species is Costertonia aggregata.

\section{Description of Costertonia aggregata sp. nov.}

Costertonia aggregata (ag.gre.ga'ta. L. fem. adj. aggregata joined together, referring to the formation of aggregates during cultivation in liquid medium).

Cells are $0 \cdot 50-0 \cdot 57 \mu \mathrm{m}$ in length and $0 \cdot 35-0 \cdot 41 \mu \mathrm{m}$ in diameter. However, rods can sometimes be longer than $4 \mu \mathrm{m}$. Properties are as described for the genus in addition to the following. Growth occurs at $10-35^{\circ} \mathrm{C}, \mathrm{pH} 6 \cdot 5-9 \cdot 0$ and with $1 \cdot 5-12 \cdot 0 \%$ sea salts. Cells form irregular aggregates during growth in liquid medium. Obligately requires $\mathrm{NaCl}, \mathrm{Ca}^{2+}$ and $\mathrm{K}^{+}$for growth. Optimal growth is observed at $\mathrm{pH} 7 \cdot 5-8 \cdot 0$ and $26-32^{\circ} \mathrm{C}$ and requires the presence of $3 \%(\mathrm{w} / \mathrm{v})$ sea salts. Reduces nitrate to nitrogen gas in API $20 \mathrm{E}$ test strip. Positive for $\beta$-glucosidase, $\beta$-galactosidase, urease, arginine dihydrolase and protease. Degrades dextrin, glycogen, Tweens 40 and 80, $\mathrm{N}$-acetyl-D-galactosamine, $\mathrm{N}$ acetyl-D-glucosamine, adonitol, L-arabinose, D-arabitol, cellobiose, L-erythritol, D-fructose, L-fucose, D-galactose, gentiobiose, $\alpha$-D-glucose, myo-inositol, $\alpha$-D-lactose, lactulose, maltose, D-mannitol, D-mannose, D-melibiose, methyl $\beta$-D-glucoside, D-raffinose, L-rhamnose, D-sorbitol, sucrose, D-trehalose, turanose, xylitol, methyl pyruvate, acetic acid, cis-aconitic acid, citric acid, D-galactonic acid lactone, Dgalacturonic acid, D-gluconic acid, D-glucuronic acid, $\beta$-hydroxybutyric acid, $\gamma$-hydroxybutyric acid, $p$-hydroxyphenylacetic acid, $\alpha$-ketoglutaric acid, $\alpha$-ketovaleric acid, DL-lactic acid, malonic acid, propionic acid, quinic acid, D-saccharic acid, succinic acid, bromosuccinic acid, glucuronamide, alaninamide, D-alanine, L-alanine, L-alanyl-glycine, L-asparagine, L-aspartic acid, L-glutamic acid, glycyl L-aspartic acid, glycyl L-glutamic acid, L-histidine, hydroxyL-proline, L-leucine, L-ornithine, L-proline, L-pyroglutamic acid, D-serine, L-serine, L-threonine, $\gamma$-aminobutyric acid, urocanic acid, inosine, uridine, phenylethylamine, putrescine, 2-aminoethanol, glycerol, DL- $\alpha$-glycerol phosphate, glucose 1-phosphate and glucose 6-phosphate as sole carbon sources. The dominant fatty acids are i-15: $0(39 \cdot 7 \%)$, i- $15: 1 \omega 10(22 \cdot 4 \%), 15: 0(7 \cdot 8 \%)$ and $16: 1 \omega 9(4 \cdot 6 \%)$.

The type strain is KOPRI $13342^{\mathrm{T}}\left(=\mathrm{KCCM} 42265^{\mathrm{T}}=\mathrm{JCM}\right.$ $13411^{\mathrm{T}}$ ), isolated from a mature marine biofilm formed on a rock-bed in Jungdongjin, Korea. The DNA G $+\mathrm{C}$ content of the type strain is $35 \cdot 8 \mathrm{~mol} \%$.

\section{Acknowledgements}

This work was supported by the 'National Research Laboratory' programme of the Ministry of Science and Technology, Korea.

\section{References}

Barbeyron, T., L'Haridon, S., Corre, E., Kloareg, B. \& Potin, P. (2001). Zobellia galactanovorans gen. nov., sp. nov., a marine species of Flavobacteriaceae isolated from a red alga, and classification of [Cytophaga] uliginosa (ZoBell and Upham 1944) Reichenbach 1989 as Zobellia uliginosa gen. nov., comb. nov. Int J Syst Evol Microbiol 51, 985-997.

Bowman, J. P. \& Nichols, D. S. (2005). Novel members of the family Flavobacteriaceae from Antarctic maritime habitats including Subsaximicrobium wynnwilliamsii gen. nov., sp. nov., Subsaximicrobium saxinquilinus sp. nov., Subsaxibacter broadyi gen. nov., sp. nov., Lacinutrix copepodicola gen. nov., sp. nov., and novel species of the genera Bizionia, Gelidibacter and Gillisia. Int J Syst Evol Microbiol 55, 1471-1486.

Bruns, A., Rohde, M. \& Berthe-Corti, L. (2001). Muricauda ruestringensis gen. nov., sp. nov., a facultatively anaerobic, appendaged bacterium from German North Sea intertidal sediment. Int J Syst Evol Microbiol 51, 1997-2006.

Cho, J. C. \& Giovannoni, S. J. (2004). Robiginitalea biformata gen. nov., sp. nov., a novel marine bacterium in the family Flavobacteriaceae with a higher G + C content. Int J Syst Evol Microbiol 54, 1101-1106.

Collins, M. D. (1985). Isoprenoid quinone analysis in bacterial classification and identification. In Chemical Methods in Bacterial Systematics, pp. 267-287. Edited by M. Goodfellow \& D. E. Minnikin. London: Academic Press.

Costerton, J. W., Lewandowski, Z., DeBeer, D., Caldwell, D., Korber, D. \& James, G. (1994). Biofilms, the customized microniche. J Bacteriol 176, 2137-2142.

Costerton, J. W., Lewandowski, Z., Caldwell, D. E., Korber, D. R. \& Lappin-Scott, H. M. (1995). Microbial biofilms. Annu Rev Microbiol 49, 711-745.

Gillan, D. C., Speksnijder, A. G. C. L., Zwart, G. \& de Ridder, C. (1998). Genetic diversity of the biofilm covering Montacuta ferruginosa (Mollusca, Bivalvia) as evaluated by denaturing gradient gel electrophoresis analysis and cloning of PCR-amplified gene fragments coding for 16S rRNA. Appl Environ Microbiol 64, 3464-3472.

Golyshin, P. N., Chernikova, T. N., Abraham, W. R., Lunsdorf, H., Timmis, K. N. \& Yakimov, M. M. (2002). Oleiphilaceae fam. nov., to include Oleiphilus messinensis gen. nov., sp. nov., a novel marine bacterium that obligately utilizes hydrocarbons. Int J Syst Evol Microbiol 52, 901-911.

Ivanova, E. P., Nedashkovskaya, O. I., Chun, J. \& 7 other authors (2001). Arenibacter gen. nov., new genus of the family Flavobacteriaceae and description of a new species, Arenibacter latericius sp. nov. Int J Syst Evol Microbiol 51, 1987-1995.

Jefferson, K. K. (2004). What drives bacteria to produce a biofilm? FEMS Microbiol Lett 236, 163-173.

Kim, S.-J., Chun, J., Bae, K. S. \& Kim, Y.-C. (2000). Polyphasic assignment of an aromatic degrading Pseudomonas sp., strain DJ77, in the genus Sphingomonas as Sphingomonas chungbukensis sp. nov. Int J Syst Evol Microbiol 50, 1641-1647. 
Kwon, K. K., Lee, H.-S., Yang, S. H. \& Kim, S.-J. (2005). Kordiimonas gwangyangensis gen. nov., sp. nov., a marine bacterium isolated from marine sediments that forms a distinct phyletic lineage (Kordiimonadales ord. nov.) in the 'Alphaproteobacteria'. Int J Syst Evol Microbiol 55, 2033-2037.

Lau, S. K. C., Tsoi, M. M. Y., Li, X., Plakhotnikova, I., Wu, M., Wong, P.-K. \& Qian, P.-Y. (2004). Loktanella hongkongensis sp. nov., a novel member of the $\alpha$-Proteobacteria originating from marine biofilms in Hong Kong waters. Int J Syst Evol Microbiol 54, 2281-2284.

Matsuo, Y., Suzuki, M., Kasai, H., Shizuri, Y. \& Harayama, S. (2003). Isolation and phylogenetic characterization of bacteria capable of inducing differentiation in the green alga Monostroma oxyspermum. Environ Microbiol 5, 25-35.

Nedashkovskaya, O. I., Suzuki, M., Vysotskii, M. V. \& Mikhailov, V. V. (2003). Arenibacter troitsensis sp. nov., isolated from marine bottom sediment. Int J Syst Evol Microbiol 53, 1287-1290.

Nedashkovskaya, O. I., Kim, S. B., Han, S. K. \& 7 other authors (2004a). Maribacter gen. nov., a new member of the family Flavobacteriaceae, isolated from marine habitats, containing the species Maribacter sedimenticola sp. nov., Maribacter aquivivus sp. nov., Maribacter orientalis sp. nov. and Maribacter ulvicola sp. nov. Int J Syst Evol Microbiol 54, 1017-1023.

Nedashkovskaya, O. I., Kim, S. B., Han, S. K., Lysenko, A. M., Mikhailov, V. V. \& Bae, K. S. (2004b). Arenibacter certesii sp. nov., a novel marine bacterium isolated from the green alga Ulva fenestrata. Int J Syst Evol Microbiol 54, 1173-1176.

Nedashkovskaya, O. I., Suzuki, M., Vancanneyt, M., Cleenwerck, I., Lysenko, A. M., Mikhailov, V. V. \& Swings, J. (2004c). Zobellia amurskyensis sp. nov., Zobellia laminariae sp. nov. and Zobellia russellii sp. nov., novel marine bacteria of the family Flavobacteriaceae. Int J Syst Evol Microbiol 54, 1643-1648.

Nedashkovskaya, O. I., Kim, S. B., Lee, K. H., Bae, K. S., Frolova, G. M., Mikhailov, V. V. \& Kim, I. S. (2005). Pibocella ponti gen. nov., sp. nov., a novel marine bacterium of the family Flavobacteriaceae isolated from the green alga Acrosiphonia sonderi. Int J Syst Evol Microbiol 55, 177-181.

Parsons, T. R., Maita, Y. \& Lalli, C. M. (1984). Artificial seawater media. In A Manual of Chemical and Biological Methods for Seawater Analysis, pp. 158-161. Oxford: Pergamon.

Pasmore, M. \& Costerton, J. W. (2003). Biofilms, bacterial signaling, and their ties to marine biology. J Ind Microbiol Biotechnol 30, 407-413.

Patel, P., Callow, M. E., Joint, I. \& Callow, J. A. (2003). Specificity in the settlement - modifying response of bacterial biofilms towards zoospores of the marine alga Enteromorpha. Environ Microbiol 5, 338-349.

Smibert, R. M. \& Krieg, N. R. (1994). Phenotypic characterization. In Methods for General and Molecular Bacteriology, pp. 607-654. Edited by P. Gerhardt, R. G. E. Murray, W. A. Wood \& N. R. Krieg. Washington, DC: American Society for Microbiology.

Sohn, J. H., Lee, J.-H., Yi, H., Chun, J., Bae, K. S., Ahn, T.-Y. \& Kim, S.-J. (2004a). Kordia algicida gen. nov., sp. nov., an algicidal bacterium isolated from red tide. Int J Syst Evol Microbiol 54, 675-680.

Sohn, J. H., Kwon, K. K., Kang, J.-H., Jung, H.-B. \& Kim, S.-J. (2004b). Novosphingobium pentaromativorans sp. nov., a high-molecularmass polycyclic aromatic hydrocarbon-degrading bacterium isolated from estuarine sediment. Int J Syst Evol Microbiol 54, 1483-1487.

Webster, N. S., Smith, L. D., Heyward, A. J., Watts, J. E. M., Webb, R. I., Blackall, L. L. \& Negri, A. P. (2004). Metamorphosis of a scleractinian coral in response to microbial biofilms. Appl Environ Microbiol 70, 1213-1221.

Yoon, J.-H., Lee, M.-H., Oh, T.-K. \& Park, Y.-H. (2005a). Muricauda flavescens sp. nov. and Muricauda aquimarina sp. nov., isolated from a salt lake near Hwajinpo Beach of the East Sea in Korea, and emended description of the genus Muricauda. Int J Syst Evol Microbiol 55, 1015-1019.

Yoon, J.-H., Kang, S.-J., Lee, S.-Y., Lee, C.-H. \& Oh, T.-K. (2005b). Maribacter dokdonensis sp. nov., isolated from sea water off a Korean island, Dokdo. Int J Syst Evol Microbiol 55, 2051-2055. 